\title{
Spectre of Doping: The Bane of Indian Athletics?
}

Doping among athletes has been brought to the spotlight among media and social networking circles. The complete information about Doping had been collected from various journals, books, online databases and various reports from international conferences. This article will give an overview of doping- incidence, agencies dealing with doping and recommendation to curb doping.

KEYWORDS: Doping, India, Athletics, Anti-doping

\section{INTRODUCTION}

Recently, an issue that has been brought to the spotlight among media and social networking circles is the matter of doping among athletes. As news of many elite contenders being disgraced on the back of the discovery of their doping violations emerge, the need arises for addressing this growing concern that threatens to become the undoing of fair sport as we know it.

\section{DOPING: DEFINITION, DRUGS USED AND RECENT DOPING METHODS}

Doping is the use of prohibited substances and methods to enhance performance by sportsmen and athletes. $^{1}$

Drugs used: The most widely known method of doping is the use of anabolic steroids or androgenic agents to allow athletes to increase muscle mass more easily. Other groups of substances used for doping along with their effects are given in Figure 1. ${ }^{2,3}$

Blood doping and gene doping are some of the forbidden techniques to enhance blood oxygenation through enhanced production of red blood cells and other vascular components. Gene doping is a relatively new concept that utilizes advanced gene therapy techniques to alter the human genes by introducing gene sequences that would cause the body to produce unnatural quantities of erythropoietin, ${ }^{4}$ a hormone that plays a key role in regulation and production of red blood cells in the blood. With the increasing variety of options for doping, and with the sports regulatory authorities playing catch - up to develop relevant tests to detect foul play, the opportunities to dope, and get away with it, increase.

\section{AGENCIES DEALING WITH DOPING}

The International Association of Athletics Federations (IAAF), in association with the World Anti-Doping Agency (WADA) and various national anti-doping agencies, since 1928, has been persistently making efforts to preclude the practices of doping and maintaining a 'zero tolerance policy with respect to doping. ${ }^{5}$ However, despite penalties against offenders, including blanket bans, being made harsher, the practice is far from eliminated.

\section{CURRENT INDIAN SCENARIO}

Indian sports, doubtless, have also felt the shame and scandal brought about by the dark cloud of doping. Since 2009, according to the National AntiDoping Agency (NADA), as many as 687 athletes have been banned for doping. This implies an average of nearly a hundred athletes each year. In the past year alone, 72 athletes have already been banned from competing. ${ }^{6}$ Such a large number of offenses places India third in the world for maximum number of doping related offenses.

Now, India threatens to rival Russia in the metaphorical race to be the nation with the most dope-offenders at the 2016 Rio Summer Olympics after two high profile athletes have been tested positive for banned substances and one has been given a four year ban for the same. A scandal of these proportions is undoubtedly marring the Indian athletes' reputation and esteem at the 
international level.

\section{RECOMMENDATIONS TO CURB DOPING}

A rigorous screening process so as to discourage potential dopers from hoping to dupe the testing process may serve as the first deterrent for aspiring athletes who might otherwise be convinced to dope. National level agencies along with state level sports authorities need to implement 24 hour testing that may be additionally prevent the use of substances that are expected to be eliminated from the bloodstream within short periods. An ironclad conviction process as well as uncompromising penalties may also compel sportspersons at all levels to be hindered from considering committing such offences. At the grassroots levels, schools and local sports organizations need to propagate the importance of the spirit of sports over the weight of winning medals and accolades in order to discourage budding sportspersons and athletes from trying to use unfair means to make quick gains.

\section{REFERENCES}

1. UNESCO. What Is Doping? [Internet]. Paris (France): UNESCO; [Date unknown] [Cited: 2017 Aug 4]. Available from: http://www.unesco.org/new/en/social-and-human- sciences/themes/anti-doping/youth-space/what-isdoping/

2. World Anti-Doping Agency. WADA Prohibited List [Internet]. Montreal (QC): World Anti-Doping Agency; 2015. Available from: https://wada-mainprod.s3.amazonaws.com/resources/files/wada2016-prohibited-list-en.pdf

3. Doping in sport: What is it and how is it being tackled?. BBC. London. [Internet]. Available from: http://www.bbc.com/sport/athletics/33997246

4. Franks T. Gene doping: Sport's Biggest Battle? BBC. London. [Internet]. Available from: https://www.bbc.com/news/magazine-25687002 5. International Association of Athletics Federations. IAAF Commitment to Healthy and Drug-Free Athletics [Internet]. Monaco: International Association of Athletics Federations; 1996 Available from: https://www.iaaf.org/about-iaaf/medicalanti-doping?utm_source=redirect \&utm_Medium=s ite-hide\&utm_campaign=link

6. Brahma B. Doping disgrace: 687 Indian athletes banned since 2009. The Times of India. Gurgaon. [Internet]. Available from: http://timesofindia.indiatimes.com/sports/rio-2016olympics/india-in-olympics-2016/miscellane ous/Doping-disgrace-687-Indian-athletes-bannedsince-2009/articleshow/53441455.cms.

\section{AUTHOR AFFILIATIONS}

1. Assistant Professor, Department of Public Health Dentistry

2. Ex-Intern

3. Assistant Professor, Department of Prosthodontics

National Dental College and Hospital, Derabassi, Punjab

Corresponding Author:

Dr. Amandeep Chopra

Assistant Professor

Department of Public Health Dentistry

National Dental College and Hospital,

Derabassi, Punjab
For article enquiry/author contact details, e-mail at: manuscriptenquiry.ihrj@gmail.com 


\section{LEGENDS}

\begin{tabular}{|c|c|}
\hline Androgenic agents & $\begin{array}{l}\text { - Allow athletes to train harder, recover quicker and build more muscle. } \\
\text { - Eg: Testosterone, dihydrotestosterone }\end{array}$ \\
\hline Narcotic Analgesics & $\begin{array}{l}\text { - Mask pain caused by injury and fatigue } \\
\text { - Eg: Methadone, hydrocodone }\end{array}$ \\
\hline Stimulants & $\begin{array}{l}\text { - Increase alertness, overcome the effects of fatigue } \\
\text { - Eg: Methamphetamine, Ritalin }\end{array}$ \\
\hline Diuretics and Masking agents & $\begin{array}{l}\text { - Hide other drug use, help in weight loss } \\
\text { - Eg: Epitestosterone, acetazolamide }\end{array}$ \\
\hline Peptide Hormones & $\begin{array}{l}\text { - Increase bulk strength and energy } \\
\text { - Build muscle } \\
\text { - Eg: Erythropoietin, Human Growth Hormone }\end{array}$ \\
\hline Glucocorticoids & $\begin{array}{l}\text { - Mask serious injury and regulate metabolism } \\
\text { - Eg: Cortisol, hydrocortisone }\end{array}$ \\
\hline Beta-Blockers & $\begin{array}{l}\text { - Keep heart rate low, reduce trembling of hands } \\
\text { - Eg: Propanolol }\end{array}$ \\
\hline
\end{tabular}

Figure 1. Commonly Used Substances for Doping In Sports and Their Effects 